ఠ

\title{
Feasibility of abdominoplasty with Cesarean section [Retraction]
}

The Editor-in-Chief and Publisher of the International Journal of Women's Health have been alerted by Dr Nadine Sherif, the corresponding author, to unacceptable levels of duplication with a previously published paper: Ali A, Essam A. Abdominoplasty Combined with Cesarean Delivery: Evaluation of the Practice. Aesthetic Plastic Surgery. 2011;35(1):80-86.

It is worth noting that this paper was peer-reviewed by two peer-reviewers and the Editor-in-Chief of the International Journal of Women's Health before publication. The paper concerned is:

Thabet WN, Hossny AS, Sherif NA. Feasibility of abdominoplasty with Cesarean section. International Journal of Women's Health. 2012;4:115-121.

\section{Publish your work in this journal}

The International Journal of Women's Health is an international, peerreviewed open-access journal publishing original research, reports, editorials, reviews and commentaries on all aspects of women's healthcare including gynecology, obstetrics, and breast cancer. The manuscript management system is completely online and includes submit your manuscript $\mid$ www.dovepress.com

Dovepress

http://dx.doi.org//0.2/47/IJWH.S42793 